\title{
THE INFLUENCE OF QUALITY OF HUMAN RESOURCES SERVICES AND STUDENTS 'INVOLVEMENT OF STUDENTS' COGNITIVE LEARNING OUTCOMES (STUDY ON STIE SUTAATMADJA AND KOLEJ UNIVERSITI ISLAM ANTARBANGSA)
}

\begin{tabular}{|c|c|}
\hline \multicolumn{2}{|c|}{$\begin{array}{c}\text { Nenden Maulida Yuliawati }{ }^{1} \text { Asep Kurniawan }{ }^{2} \\
\text { Sekolah Tinggi Ilmu Ekonomi Sutaatmadja, Subang, Indonesia } \\
\text { nendenmaulidayuliawati@gmail.com }\end{array}$} \\
\hline INFO ARTIKEL & ABSTRAK/ABSTRACT \\
\hline $\begin{array}{l}\text { Histori Artikel : } \\
\text { Tgl. Masuk : } 30 \text { oktober } 2019 \\
\text { Tgl. Diterima : } 22 \text { November } 2019 \\
\text { Tersedia Online : } 23 \text { Desember } 2019 \\
\text { Keywords: } \\
\text { Services, Human Resources, } \\
\text { Students, Learning }\end{array}$ & $\begin{array}{l}\text { The purpose of this study was to determine } \\
\text { whether there was an influence or not from the quality of } \\
\text { human resource services and student involvement on } \\
\text { student cognitive learning outcomes. The approach used is } \\
\text { multiple linear regression, based on the T test and F test for } \\
\text { data processing. The main finding is the effect found to } \\
\text { assess student cognitive learning outcomes. The results of } \\
\text { this multiple linear regression approach provide specific } \\
\text { guidance for educational institutions in improving student } \\
\text { cognitive learning outcomes. }\end{array}$ \\
\hline
\end{tabular}

\section{PENDAHULUAN}

Pendidikan

sesungguhnya

memiliki peran yang sangat penting dalam kehidupan berbangsa dan bernegara, yakni dalam upaya menciptakan sumber daya manusia yang berkualitas. Pendidikan merupakan suatu faktor kebutuhan dasar untuk setiap manusia, karena melalui pendidikan upaya peningkatan kesejahteraan rakyat dapat diwujudkan. Pendidikan tidak hanya berperan besar dalam kemajuan bangsa, melainkan juga berkaitan dengan pasar bebas yang semakin kompetitif (I Ketut Sudarsana, 2015). Melalui pendidikan, dapat menciptakan tenaga kerja yang tidak hanya kaya akan pengetahuan teoritis melainkan juga praktis, penguasaan teknologi, dan memiliki keahlian khusus. Hal inilah yang kemudian menjadi dasar evaluasi dan peningkatan pendidikan di setiap negara secara berkesinambungan. Pendidikan dapat mengembangkan berbagai potensi yang dimilikinya secara optimal, yaitu pengembangan potensi individu yang setinggi-tingginya dalam aspek fisik, intelektual, emosional, sosial dan spiritual, sesuai dengan tahap perkembangan serta karakteristik lingkungan fisik dan lingkungan sosio-budaya dimana dia hidup. (Agus Taufiq, 2014)

Pendidikan diterapkan di berbagai tingkatan, mulai dari Sekolah Dasar 
hingga Perguruan Tinggi. Perguruan Tinggi merupakan penyelenggara pendidikan akademik bagi mahasiswa. Berdasarkan data yang diperoleh dari Pusat Statistik Pendidikan Badan Penelitian dan Pengembangan Departemen Pendidikan Nasional Republik Indonesia menyebutkan bahwa jumlah lembaga penyelenggara pendidikan perguruan tinggi mengalami peningkatan setiap tahunnya. Sampai dengan tahun 2010 tercatat 3011 perguruan tinggi diselenggarakan di Indonesia. Perguruan tinggi diharapkan menyelenggarakan pendidikan yang berkualitas bagi mahasiswa sehingga menghasilkan sumber daya manusia yang berilmu, cakap dan kreatif. Semakin bertambah jumlah perguruan tinggi maka semakin meningkat pula jumlah sumber daya manusia berkualitas yang dihasilkan perguruan tinggi (Khafiizh Hastuti, 2012).

Salah satu faktor yang menentukan kualitas perguruan tinggi adalah dengan menilai kinerja layanan pendidikan terhadap mahasiswa (Douglas et al., 2006; Petruzzelis et al., 2006). Pendekatan ini berfokus pada memperlakukan mahasiswa sebagai konsumen utama dari layanan pendidikan perguruan tinggi, dengan menggunakan penilaian kualitas dan kepuasan yang dirasakan mahasiswa sebagai ukuran utama kinerja layanan perguruan tinggi (Hill, 1995; Kotze' dan Plessis, 2003). Kepuasan pengguna jasa (mahasiswa) juga menjadi ukuran keberhasilan lembaga pendidikan dalam mengelola lembaganya serta mengutamakan mutu akademik sebagai produk jasa yang harus dicapai (Nurul Qomariah, 2012). Salah satu bentuk tanggung jawab lembaga pendidikan terhadap pengguna jasa adalah menjaga kualitas pendidikan melalui pengakuan dari sebuah Badan Akreditasi Nasional. Berdasarkan keputusan Mendiknas RI No. 004/U/2002 bahwa akreditasi terhadap program studi merupakan bentuk pertanggungjawaban Perguruan Tinggi kepada publik.

Pelayanan pendidikan yang diberikan oleh Perguruan Tinggi ini, diharapkan mampu menjadi pendukung terhadap hasil belajar kognitif mahasiswa. Hasil belajar kognitif merupakan gambaran tingkat penguasaan mahasiswa terhadap mata pelajaran yang ditempuhnya atau penguasaan mahasiswa terhadap sesuatu dalam kegiatan pembelajaran berupa pengetahuan atau teori yang melibatkan pengetahuan dan pengembangan keterampilan intelektual yang meliputi penarikan kembali atau pengakuan dari fakta-fakta, pola prosedural, dan konsep dalam pengembangan kemampuan dan keterampilan intelektual peserta didik (O'Brei, 2007,p.10; Potter \& Kustra, 2012,p.1; Kenedy \& Ryan, 2012,p.5). Hasil belajar kognitif terdiri atas enam aspek yaitu: remembering (mengingat), 
understanding (memahami), applying (mengaplikasikan), analyzing (menganalisis), evaluating (mengevaluasi), dan creating (membuat) (Munzenmaier \& Rubin, 2013,p.18; Orey, 2010,p.11).

Hasil belajar kognitif mahasiswa di Sekolah Tinggi Ilmu Ekonomi Sutaatmadja dan Kolej Universiti Islam Antarbangsa Selangor dipengaruhi oleh faktor internal (pribadi mahasiswa) maupun faktor eksternal. Kualitas layanan sumber daya manusia menjadi faktor pendukung eksternal terhadap hasil belajar kognitif mahasiswa. Disini, peran dosen, bagian akademik, asisten Perguruan Tinggi, maupun satpam diharapkan mampu mendukung proses pembelajaran yang berlangsung di perguruan tinggi agar mampu mewujudkan harapan mahasiswa. Untuk menilai suatu pelayanan mempunyai kualitas yang baik atau tidak, bukan hanya menggunakan standar pelayanan yang ada, tetapi diukur berdasarkan persepsi mahasiswa (Bambang Sancoko, 2010)

Selain layanan pendidikan yang berkualitas, mahasiswa di Sekolah Tinggi IImu Ekonomi Sutaatmadja dan Kolej Universiti perlu berperan aktif dalam proses pembelajaran. Keterlibatan mahasiswa yang aktif terhadap proses pembelajaran tentu dapat merasakan hasil belajar kognitif yang lebih unggul dibandingkan mahasiswa yang pasif. Upaya meningkatkan keterlibatan aktif mahasiswa dalam proses pembelajaran merupakan suatu upaya mengembangkan kemampuan mahasiswa belajar mandiri. Hal tersebut dapat dilakukan dengan membiasakan mahasiswa belajar melalui berbagai kegiatan seperti membaca, menulis, mendengarkan, mendiskusikan, dan bertanya dalam proses belajarnya. Belajar mandiri mencakup kemampuan menemukan cara memecahkan masalah dalam belajar, dengan mencari sumbersumber yang dapat membantu, dan mendisiplinkan diri (Soekamto, Wardani, \& Winataputra, 1993). Keterlibatan mahasiswa diharapkan menjadi bekal mahasiswa untuk mendapatkan hasil belajar kognitif yang lebih baik lagi.

\section{KERANGKA TEORITIS DAN PENGEMBANGAN HIPOTESIS}

\section{Kualitas Sumber Daya Manusia}

Menurut Sayuti Hasibuan (2000, p3), sumber daya manusia adalah semua manusia yang terlibat di dalam suatu organisasi dalam mengupayakan terwujudnya tujuan organisasi tersebut. Nawawi (2003, p37) membagi pengertian SDM menjadi dua, yaitu pengertian secara makro dan mikro. Pengertian sumber daya manusia secara makro adalah semua manusia sebagai penduduk atau warga negara suatu negara atau dalam batas wilayah tertentu yang sudah memasuki usia angkatan kerja, baik yang sudah maupun yang belum memperoleh pekerjaan (lapangan kerja). Pengertian 
SDM secara mikro adalah manusia atau orang yang bekerja menjadi anggota suatu organisasi yang disebut personil, pegawai, karyawan, pekerja, tenaga kerja, dll. Jadi sumber daya manusia adalah semua orang yang terlibat yang bekerja untuk mencapai tujuan perusahaan

Sumber daya manusia berkualitas tinggi menurut Ndaraha (1999) adalah sumber daya manusia yang menciptakan bukan saja nilai komparatif tetapi juga nilai kompetitif-generatif-inovatif dengan menggunakan energi tertinggi seperti: intelligence, creativity dan imagination; tidak lagi sematamata menggunakan energi kasar, seperti bahan mentah, lahan air, tenaga, otot dan sebagainya. Menurut Sugeng (2002), kualitas sumber daya manusia merupakan pengetahuan, keterampilan, dan kemampuan seseorang yang dapat digunakan untuk menghasilkan layanan professional. Abdullah (1990) sependapat bahwa kualitas sumber daya manusia selalu tidak akan terlepas dari sebuah kerja professional. Sehingga sebuah kualitas kerja, haruslah dilibatkan dalam konteks kerja yang merupakan profesi seseorang.

Manajemen sumber daya manusia selalu mengaitkan hubungan antara pemberi layanan (pihak yang terlibat seperti dosen \& bagian akademik) dengan pelanggan (mahasiswa). Mahasiswa memiliki persepsi terhadap layanan pendidikan perguruan tinggi. Menurut Dwiyanto, 1995) pelayanan yang berkualitas menunjukan kondisi dimana sumber daya manusia yang terlibat dapat memberikan kepuasan bagi pelanggan (mahasiswa).

Layanan sumber daya manusia dalam konteks pendidikan yang berkualitas diukur berdasarkan : (1) Dosen mampu menyiapkan materi pada saat perkuliahan dimulai, (2) Dosen mampu menciptakan suasana perkuliahan yang menarik dan kondusif, (3) Dosen mampu menyampaikan materi pembelajaran dengan jelas, (4) Dosen mampu menyampaikan materi pembelajaran yang sesuai dengan silabus mata kuliah, (5) Dosen dan bagian akademik mempersiapkan mahasiswa dalam memulai karir, (6) Bagian administrasi dapat melayani mahasiswa secara baik (Lola C. Duque and Jhon R. Weeks, 2010). Sumber daya manusia ini menjadi faktor yang diharapkan berpengaruh terhadap hasil belajar kognitif mahasiswa.Karena itu peneliti mengharapkan:

H1 : Kualitas layanan sumber daya manusia berpengaruh positif terhadap hasil belajar kognitif mahasiswa

\section{Peran Mahasiswa}

Mahasiswa adalah sebagai pelaku utama dan agent of change, dalam gerakan-gerakan pembaharuan memiliki makna yaitu sekumpulan manusia intelektual, memandang segala sesuatu dengan pikiran jernih, positif, kritis yang bertanggung jawab serta dewasa secara moril, karena mahasiswa akan dituntut 
tanggung jawab akademisnya dalam menghasilkan sebuah karya yang berguna bagi kehidupan lingkungan. Mahasiswa dalam peraturan pemerintah RI No.30 tahun 1990 adalah peserta didik yang terdaftar dan belajar di perguruan tinggi tertentu. Menurut Sarwono dalam Ardana kurniaji (2012), mahasiswa adalah setiap orang yang secara resmi terdaftar untuk mengikuti pelajaran di perguruan tinggi dengan batas usia sekitar 18-30 tahun. Mahasiswa merupakan suatu kelompok dalam masyarakat yang memperoleh statusnya karena ikatan dengan perguruan tinggi.

Menurut Drs. M. Achmad Icksan dalam Ardana Kurniaji (2012) bahwa mahasiswa pasti berhubungan dengan universitas namun mahasiswa di dalam universitas tidak hanya sebagai anggota masyarakat kampus, tapi mahasiswa harus ikut berperan dalam menentukan program-program, aturan-aturan dan kesejahteraan dari lembaga yang ada dikampus. Mahasiswa sebagai salah satu wadah pemikiran demi kemajuan masa depan bangsa, dalam hal ini seorang mahasiswa harus dituntut untuk mempunyai pemikiran yang sifatnya holistic dan ofensif demi masa depan Indonesia yang lebih baik, yang dapat digalinya pemikiran tersebut dengan penanganan masalah-masalah kecil, sehingga dari pengalaman masalah kecil tersebut dapat membentuk seorang mahasiswa menjadi kritis.
Peran mahasiswa ini mempunyai keterlibatan terhadap hasil belajar secara kognitif. Mahasiswa yang terbiasa hanya mendengarkan kuliah atau yang kurang terbiasa mengemukakan pendapat, nampak kurang terlibat aktif dalam memecahkan masalah. Penerapan strategi pembelajaran yang aktif harus dilakukan oleh para dosen bertujuan untuk mendorong keterlibatan aktif mahasiswa (Abidin Zaenal, 2005). Keterlibatan mahasiswa dalam pembelajaran aktif diatas menunjukkan adanya beberapa indikasi aktifitas belajar yang mandiri, berpartisipasi aktif, bersikap kritis, kolaboratif, dan mengevaluasi-diri atau proses refleksi. Dosen berperan membantu dan mengarahkan agar kegiatan-kegiatan mandiri yang dilakukan mahasiswa tersebut berjalan sesuai dengan tujuan pembelajaran.

Keterlibatan mahasiswa ini diukur berdasarkan beberapa indikator diantarantya: (1) Mahasiswa dapat mengelola, menggunakan, dan menganalisis informasi dengan baik, (2) Mahasiswa mampu berkomunikasi secara efektif dengan memahami, menulis dan berbicara dengan baik, (3) Mahasiswa dapat melakukan perencanaan dan kemampuan berorganisasi, (4) Mahasiswa selalu percaya diri, mandiri dan berinisiatif terhadap pribadinya, (5) Mahasiswa memiliki pandangan dan cara sendiri untuk berinteraksi dengan orang lain, Mahasiswa dapat menilai etika pribadinya 
sendiri (Lola C. Duque and Jhon R. Weeks, 2010). Menurut (Astin,1999) berpendapat bahwa mahasiswa yang lebih aktif dalam pengalaman akademis, akan memperoleh pembelajaran dan pengembangan pribadi yang lebih baik. Bedasarkan penjelasan tersebut, peneliti mengharapkan :

H2 : Keterlibatan mahasiswa berpengaruh positif terhadap hasil belajar kognitif mahasiswa

\section{Hasil Belajar Kognitif}

Belajar merupakan bagian yang tidak terpisahkan dalam kehidupan manusia. Belajar tidak hanya melibatkan penguasaan suatu kemampuan atau masalah akademik baru,tetapi juga perkembangan emosi, interaksi sosial, dan perkembangan kepribadian sosial. Belajar merupakan proses dalam diri individu yang berinteraksi dengan lingkungan untuk mendapatkan perubahan dalam perilakunya. Belajar adalah aktivitas mental/psikis yang berlangsung dalam interaksi aktif dengan lingkungan yang menghasilkan perubahan-perubahan. Perubahan itu diperoleh melalui usaha (bukan karena kematangan), menetap dalam waktu yang relatif lama dan merupakan hasil pengalaman. (Purwanto, 2009)

Menurut Popi Sopiyatin (2010) mengemukakan bahwa hasil belajar adalah kemampuan-kemampuan yang dimiliki siswa setelah ia menerima pengalaman belajarnya. Sedangkan menurut Mulyani Sumantri (2007) Hasil Belajar adalah perubahan perilaku yang relatif menetap dalam diri seseorang dengan lingkungannya. Berdasarkan pengertian di atas, dapat disimpulkan bahwa belajar adalah proses perubahan tingkah laku seseorang secara terus menerus melalui pelatihan dan pengalaman.

Menurut Syah Muhibin (2009) Kognitif berasal dari kata cognition yang padanan katanya knowing, yang berarti mengetahui. Dalam arti yang luas, kognitif adalah perolehan, penataan, dan penggunaan pengetahuan. Dalam perkembangan selanjutnya, istilah kognitif menjadi populer sebagai salah satu domain atau wilayah/ranah psikologis manusia yang meliputi setiap perilaku mental yang berhubungan dengan pemahaman, pertimbangan, pengolahan informasi, pemecahan masalah, kesengajaan, dan keyakinan. Ranah kognitif yaitu kemampuan yang selalu dituntut pada anak didik untuk dikuasai karena menjadi dasar bagi penguasaan ilmu pengetahuan (Rahmah Noer, 2012). 
Hasil belajar kognitif meliputi kemampuan yang menyatakan kembali suatu konsep atau prinsip yang telah dipelajari dan kemampuan intelektual (Imamah, 2013). Hasil belajar kognitif pada mahasiswa dapat diukur berdasarkan beberapa indikator, diantaranya : (1) Mahasiswa dapat mengetahui dan mengingat dengan baik spesifikasi lokasi tinggal/berada, (2) Mahasiswa memiliki kemampuan berorganisasi di lingkungan kampus maupun masyarakat, (3) Mahasiswa memahami hubungan yang terjadi antara global dengan lokal, (4) Mahasiswa mampu menganalisis karakteristik dan pola hidup orangorang disekitarnya, (5) Mahasiswa dapat memahami kejadian rumit yang terjadi antara lingkungan dengan masyarakat, (6) Mahasiswa memiliki pengetahuan yang baik mengenai metode dan teknik analisis geospasial ( kualitatif dan kuantitatif), Mahasiswa dapat mengungkapkan sudut pandang yang berbeda terhadap isu-isu yang berada di daerahnya. Berdasarkan penjalasan diatas, peneliti berharap :

H3 : Kualitas layanan sumber daya manusia dan keterlibatan mahasiswa berpengaruh positif terhadap hasil belajar kognitif.

\section{METODOLOGI PENELITIAN}

Metode penelitan pada dasarnya merupakan cara ilmiah untuk mendapatkan data dengan tujuan dan kegunaan tertentu. (Sugiyono, 2014). Dalam penelitian ini, jenis penelitian yang digunakan merupakan penelitian survey. Penelitian survei adalah penelitian kuantitatif dimana peneliti menanyakan ke beberapa orang (yang disebut dengan responden) tentang keyakinan, pendapat, karakteristik suatu obyek dan perilaku yang telah lalu atau sekarang (Sugiyono, 2014). Adapun variabel yang diamati dalam penelitian ini terdiri dari dua variabel bebas $(\mathrm{X})$ dan satu variabel terikat $(\mathrm{Y})$. Variabel bebas dalam penelitian ini adalah kualitas layanan sumber daya manusia dan keterlibatan mahasiswa. Variabel terikat dalam penelitian ini adalah hasil belajar kognitif mahasiswa.

Teknik analisis data yang digunakan pada penelitian ini adalah statistik deskriptif. Statistik deskriptif adalah statistik yang digunakan untuk menganalisis data dengan cara mendeskripsikan atau menggambarkan data yang telah berkumpul sebagaimana adanya tanpa bermaksud membuat kesimpulan yang berlaku untuk umum atau generalisasi (Sugiyono, 2014). Sedangkan hipotesis dalam penelitian ini 
akan diuji menggunakan teknik analisis regresi linear berganda. Analisis regresi akan menguji probabilitas terjadinya variabel terikat dapat diprediksi dengan variabel (Ghozali, 2013).

Pengumpulan data Analisis Spesifikasi penelitian yang digunakan adalah deskriptif analisis yang bertujuan untuk membuat deskripsi atau gambaran mengenai fakta-fakta, sifat-sifat serta hubungan antara fenomena yang diselidiki (Nasir, 1999). Penelitian deskriptif ini merupakan penelitian yang tidak dimaksudkan untuk menguji hipotesis tertentu tetapi hanya menggambarkan apa adanya tentang sesuatu variabel, gejala atau keadaan (Arikunto, 1993). Pengumpulan data dengan melukiskan sebagaimana adanya, tidak diiringi dengan ulasan atau pandangan atau analisis dari penulis (Bachtiar, 1997).

\section{Jenis, Sumber dan Teknik Pengumpulan Data}

Jenis data yang digunakan dalam penelitian ini adalah data kuantitatif. Data kuantitatif yaitu data yang disajikan dalam bentuk angka-angka, menunjukan nilai terhadap besarnya variable yang di wakiliny Jenis data yang digunakan dalam penelitian adalah data primer dan data sekunder sebagai berikut :

a. Data Primer, yaitu jenis data yang diperoleh dari sumber pertama baik dari individu atau dari perorangan seperti hasil wawancara atau hasil pengisian kuesioner yang biasa dilakukan oleh peneliti. Menurut Sanusi (2016) data primer yaitu data yang pertama kali dicatat dan dikumpulkan oleh peneliti. Data primer dalam penelitian ini adalah informasi yang di kumpulkan berdasarkan jawaban responden terhadap kuesioner. Data primer penelitian ini dari pendapat atau persepsi mahasiswa pada Sekolah Tinggi IImu Ekonomi Sutaatmadja dan Kolej Universiti Islam Antarbangsa Selangor.

b. Data yang digunakan dalam penelitian ini, selain menggunakan data primer juga menggunakan data sekunder. Data Sekunder yaitu data primer yang telah diolah lebih lanjut dan disajikan baik oleh pihak pengumpul data primer atau oleh pihak lain misalnya dalam bentuk tabel-tabel atau diagramdiagram. Data sekunder didapat dengan mengumpulkan bahan-bahan atau sumber-sumber bacaan atau kepustakaan. Data sekunder diperoleh peneliti secara tidak langsung yaitu melalui media perantara (diperoleh dan dicatat oleh pihak luar) dengan menggunakan cara membaca dan mengutip baik secara lagnsung maupun tidak langsung dari literatureliteratur yang berhubungan dengan variable penelitian.

Dalam suatu penelitian, pengumpulan data perlu dilakukan secara berhati-hati, sistematis, dan cermat, sehingga data yang dikumpulkan relevan 
dengan masalah penelitian yang akan dicari jawabannya sebagai upaya menguji kebenaran hipotesis yang telah dirumuskan. Untuk itu metode pengumpulan data yang digunakan dalam penelitian ini adalah sebagai berikut :

a. Kuesioner, yaitu teknik pengumpulan data yang dilakukan dengan cara memberikan sejumlah pertanyaan tertulis secara terstruktur kepada responden penelitian berkaitan dengan tanggapannya terhadap berbagai variabel yang di teliti dalam penelitian ini.

Tabel 3.1

Skor Jawaban Respnden (Skala Likert)

\begin{tabular}{|c|c|c|}
\hline No. & Jawaban Responden & Skor \\
\hline 1 & Sangat Setuju (SS) & 5 \\
\hline 2 & Setuju (S) & 4 \\
\hline 3 & Netral (N) & 3 \\
\hline 4 & Tidak Setuju (TS) & 2 \\
\hline 5 & Sangat Tidak Setuju & 1 \\
\hline
\end{tabular}

Sumber : Data

Primer yang diolah, 2018

Skala Likert digunakan untuk mengukur sikap, pendapat dan persepsi seseorang atau sekelompok orang tentang fenomena sosial. Dengan skala likert, maka variabel yang akan diukur dijabarkan menjadi indikator variabel. Kemudian indikator tersebut dijadikan sebagai titik tolak untuk menyusun item-item instrument yang dapat pernyataan atau pertanyaan (Sugiyono, 2014).

b. Studi Kepustakaan, yaitu penelitian yang dilakukan dengan cara mendapatkan suatu keterangan masukanmasukan yang bersifat ilmiah yang didapat dari buku -buku, jurnal dan sebagainya, serta mencari pendapat-pendapat yang bersifat teritis dan relevan dengan objek pembahasan yang berhubungan dengan topik analisis faktor-faktor yang mempengaruhi kinerja sistem informasi akuntansi. Sehingga diperoleh informasi sebagai dasar teori dan acuan untuk mngolah data-data yang diperoleh.

\section{Populasi dan Sampel}

Populasi adalah wilayah generalisasi yang terjadi atas objek atau subjek yang mempunyai kualitas dan karakter tertentu yang ditetapkan oleh peneliti untuk dipelajari dan kemudian ditarik kesimpulan (Sugiyono,2003). Populasi dalam penelitian ini adalah seluruh mahasiswa Sekolah Tinggi Ilmu Ekonomi Sutaatmadja dan Kolej Universiti Islam Antarbangsa Selangor

Dari pengertian di atas dapat diketahui populasi merupakan objek atau subjek yang berada pada suatu wilayah dan memenuhui syarat-syarat tertentu berkaitan dengan masalah penelitian. Berdasarkan penjelasan diatas, maka sampel yang diambil penulis dalam penelitian ini adalah 82 mahasiswa pada Sekolah Tinggi Ilmu Ekonomi Sutaatmadja dan Kolej Universiti Islam Antarbangsa Selangor.

\section{Teknik Pemilihan Data}

Analisa data utama yang digunakan adalah secara kuantitatif, yaitu 
penggambaran dengan kata-kata atau kalimat-kalimat yang dipisahkan-pisahkan menurut kategori untuk memperoleh kesimpulan. Proses analisis data meliputi kegiatan menelaah seluruh data yang tersedia dari berbagai sumber yang diperoleh. Peneliti juga melakukan perbandingan antara teori secara umum dengan kenyataan yang terjadi di lapangan yang disusun secara sistematis dalam bentuk tugas akhir.

\section{Metode Pengumpulan Data}

Metode pengumpulan data yang digunakan dalam penelitian ini adalah metode survey. Metode survey yang digunakan adalah dengan cara menyebarkan kuesioner kepada responden dalam bentuk daftar pertanyaan yang disusun secara tertulis. Data kuesioner terdiri dari profil responden, beberapa bagian pertanyaan, masing-masing bagian terdapat beberapa item pertanyaan.

\section{Operasional Variabel}

Menurut Sugiyono (2014) pengertian variabel adalah sesuatu hal yang berbentuk apa saja yang di tetapkan oleh peneliti untuk dipelajari sehingga diperoleh informasi tentang hal tersebut, kemudian di tarik kesimpulan. Variabel dependen dalam penelitian ini adalah hasil belajar kognitif mahasiswa, sedangkan untuk variabel independen adalah kualitas layanan sumber daya manusia dan keterlibatan mahasiswa.

\section{HASIL DAN PEMBAHASAN}

\section{Hasil Analis Deskriptif}

Analis Deskriptif dalam penelitian ini menjelaskan data responden yang berisi nama, program studi, usia, universitas dan tanggapan responden tentang variabel yang diteliti yaitu pengaruh kualitas layanan sumber daya manusia dan keterlibatan mahasiswa terhadap hasil belajar kognitif mahasiswa.

\section{Deskriptif Data Penelitian}

Penelitian ini digunakan untuk mengetahui dan mengungkap tentang pengaruh kualitas layanan sumber daya manusia dan keterlibatan mahasiswa terhadap hasil belajar kognitif mahasiswa. Data penelitian ini diambil dengan metode survey. Metode survey ini dimulai dengan menyebarkan kuesioner online kepada responden dalam bentuk pertanyaan melalui google forms. Kuesioner ini bertujuan untuk memperoleh data yang berupa jawaban dari responden. Kuesioner ini kemudian di analisis menggunakan analisis deskriptif dan analisis regresi linear berganda. Pembagian kuesioner tersebut dimulai pada tanggal 30 juli 2018 sampai dengan 30 Agustus 2018.. Jumlah kuesioner yang diisi oleh responden sebanyak 82 orang. Menurut Uma Sekaran (2006) jumlah minimum sampel sebanyak 30 , maka sampel penelitian ini telah memenuhi kriteria sampel minimum dan bias di generelisasikan 


\section{Analisis Pengujian Kualitas Data}

Dalam analisis pengujian kualitas data yang digunakan adalah uji validitas dan uji realibilitas dengan menggunakan bantuan software SPSS versi 22.

\section{Hasil Uji Reliabilitas}

Uji Reliabilitas dimaksudkan untuk mengukur tingkat konsistensi instrumen penelitian. pada penelitian ini digunakan teknik perhitungan reliabilitas koefisisen Cronbach Alpha, dengan alasan perhitungan dengan teknik ini akan memberikan harga yang lebih kecil atau sama besar dengan reliabilitas yang sebenarnya (Anzwar, 1997). Suatu instrument dikatakan reliabel atau tidak jika nilai cronbach alpha > 0,70 (Nunnaly, 1987). Tabel berikut menunjukan hasil uji reliabilitas dari tujuh variabel dengan 100 sampel responden dan menggunakan bantuan software SPPS versi 22:

Tabel 4.1

Uji Reliabilitas

\begin{tabular}{|l|l|l|}
\hline Variabel & Cronbach's Alpha & N of item \\
\hline X1 & 0.822 & 6 \\
\hline X2 & 0.842 & 6 \\
\hline Y & 0.739 & 7 \\
\hline
\end{tabular}

Berdasarkan tabel 4.1 di atas terlihat bahwa nilai koefisien reliabilitas dari variabel kualitas layanan sumber daya manusia adalah 0,822 lebih besar dari 0,70 sehingga dapat disimpulkan bahwa alat ukur yang digunakan reliabel dan jawaban-jawaban yang telah diberikan oleh responden dapat dipercaya.
Berdasarkan tabel 4.1 di atas terlihat bahwa nilai koefisien reliabilitas dari variabel keterlibatan mahasiswa adalah 0.842 lebih besar dari 0,70 sehingga dapat disimpulkan bahwa alat ukur yang digunakan reliabel dan jawaban-jawaban yang telah diberikan oleh responden dapat dipercaya. Berdasarkan tabel 4.1 di atas terlihat bahwa nilai koefisien reliabilitas dari variabel hasil belajar kognitif adalah 0.739 lebih besar dari 0,70 sehingga dapat disimpulkan bahwa alat ukur yang digunakan reliabel dan jawaban-jawaban yang telah diberikan oleh responden dapat dipercaya.

\section{Hasil Uji Validitas}

Uji Validitas digunakan untuk mengukur sah atau valid tidaknya suatu kuesioner. Suatu kuesioner dikatakan valid jika pertanyaan dalam kuesioner mampu untuk mengungkapkan sesuatu yang akan diukur oleh kuesioner tersebut. Pada penelitian ini uji validitas dilakukan dengan menggunakan teknik korelasi Product Moment dari Pearson (Azwar, 1997) yaitu mengkorelasikan skor item dengan skor total. Suatu item valid atau gugur adalah dengan membandingkan antara $r$ hitung dengan $r$ tabel dimana $r$ hitung lebih besar dari $r$ tabel. Tabel berikut menunjukan hasil uji validitas dari tiga variabel dengan 82 sampel responden dan menggunakan bantuan software SPSS versi 22: 
Tabel 4.2

Uji Validitas

\begin{tabular}{|c|c|c|c|c|}
\hline ari & Butir & Correcte & r-tal & Ketera \\
\hline & $\begin{array}{l}\text { Pertan } \\
\text { yaan }\end{array}$ & $\begin{array}{l}\text { d Item- } \\
\text { Total } \\
\text { Correlati } \\
\text { on }\end{array}$ & & in \\
\hline $\mathrm{X} 1$ & 1 & 0,522 & 0,220 & Valid \\
\hline & 2 & 0,803 & 0,220 & Valid \\
\hline & 3 & 0,795 & 0,220 & Valid \\
\hline & 4 & 0,702 & 0,220 & Valid \\
\hline & 5 & 0,736 & 0,220 & Valid \\
\hline & 6 & 0,796 & 0,220 & Valid \\
\hline $\mathrm{X} 2$ & 1 & 0,743 & 0,220 & Valid \\
\hline & 2 & 0,799 & 0,220 & Valid \\
\hline & 3 & 0,720 & 0,220 & Valid \\
\hline & 4 & 0,740 & 0,220 & Valid \\
\hline & 5 & 0,701 & 0,220 & Valid \\
\hline & 6 & 0,787 & 0,220 & Valid \\
\hline$Y$ & 1 & 0,470 & 0,220 & Valid \\
\hline & 2 & 0,680 & 0,220 & Valid \\
\hline & 3 & 0,704 & 0,220 & Valid \\
\hline & 4 & 0,727 & 0,220 & Valid \\
\hline & 5 & 0,759 & 0,220 & Valid \\
\hline & 6 & 0,501 & 0,220 & Valid \\
\hline & 7 & 0,536 & 0,220 & Valid \\
\hline
\end{tabular}

Berdasarkan tabel 4.2 di atas dapat dilihat bahwa nilai koefisien korelasi dari setiap butir pernyataan variabel kualitas sumber daya manusia lebih besar dari nilai $r$ tabel 0,220 . Hasil uji validitas ini menunjukan hahwa semua butir pernyataan adalah valid dan tepat/mampu untuk mengukur variabel kualitas sumber daya manusia dalam penelitian ini. Jadi, berdasarkan hasil uji validitas, kuesioner telah tepat untuk dijadikan alat mengumpulkan data mengenai variabel keterlibatan pemakai dalam pengembangan sistem informasi.

Berdasarkan tabel 4.2 di atas dapat dilihat bahwa nilai koefisien korelasi dari setiap butir pernyataan keterlibatan mahasiswa lebih besar dari nilai $r$ tabel 0,220 . Hasil uji validitas ini menunjukan hahwa semua butir pernyataan adalah valid dan tepat/mampu untuk mengukur variabel keterlibatan mahasiswa dalam penelitian ini. Jadi, berdasarkan hasil uji validitas, kuesioner telah tepat untuk dijadikan alat mengumpulkan data mengenai variabel kapabilitas personal sistem informasi.

Berdasarkan tabel 4.2 di atas dapat dilihat bahwa nilai koefisien korelasi dari setiap butir pernyataan variabel hasil belajar kognitif mahasiswa lebih besar dari nilai $r$ tabel 0,220 . Hasil uji validitas ini menunjukan hahwa semua butir pernyataan adalah valid dan tepat/mampu untuk mengukur variabel hasil belajar kognitif mahasiswa dalam penelitian ini. Jadi, berdasarkan hasil uji validitas, kuesioner telah tepat untuk dijadikan alat mengumpulkan data mengenai variabel kapabilitas personal sistem informasi.

\section{Uji Asumsi Klasik}

Sebelum hasil regresi diuji lebih lanjut, terlebih dahulu dilakukan uji asumsi klasik. Uji asumsi klasik dilakukan untuk memperoleh penelitian yang akurat. Pengujiannya meliputi uji normalitas, uji multikolinearitas, uji heteroskedastisitas, dan uji linearitas. Berikut adalah hasil dari pengujian keempat asumsi tersebut.

\section{Uji Normalitas}

Uji Normalitas dilakukan untuk melihat apakah variabel bebas dan 
variabel terikat mempunyai distribusi normal. Maksud dari data ditribusi normal adalah data akan mengikuti arah garis diagonal dan menyebar disekitar garis diagonal. Dalam penelitian ini, peneliti menggunakan uji normalitas dengan analisis grafik dan uji KolmogorovSmirnov. Berikut hasil dari uji normalitas :

\section{Analisis Grafik}

Berikut adalah hasil dari analisis grafik untuk uji normalitas dengan menggunakan analisis histogram dan grafik P-Plot.

\section{Gambar 4.1}

\section{Analisis Histogram}

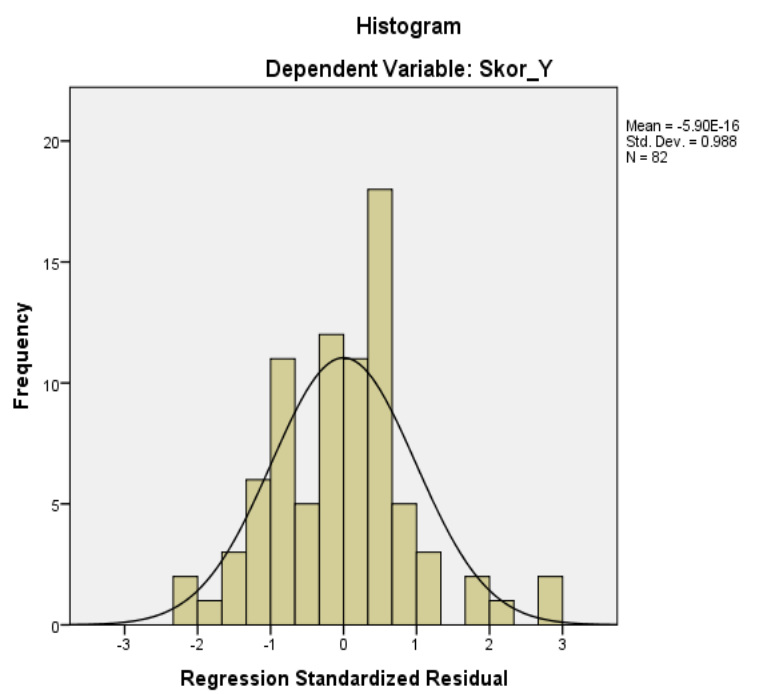

Grafik histogram pada gambar 4.1 menunjukkan bahwa pola berdistribusi normal, karena grafik tidak menceng ke kiri atau ke kanan melainkan membentuk pola bel atau lonceng, sehingga dapat disimpulkan bahwa model regresi dalam penelitian ini telah berdistribusi secara normal. Hasil ini juga diperkuat dengan hasil uji grafik normal P-Plot berikut.

\section{Gambar 4.2}

Normal P-plot

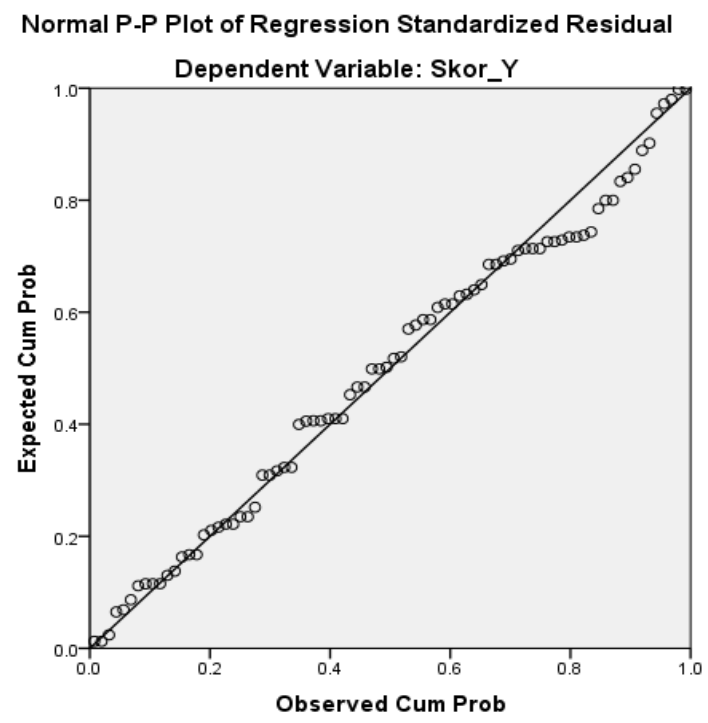

Grafik Normal P-Plot pada gambar 4.2 menunjukkan bahwa titik-titik menyebar di sekitar garis diagonal dan mengikuti arah garis diagonal, sehingga dapat disimpulkan bahwa model regresi telah memenuhi asumsi normalitas

\section{Uji Multikolinearitas}

Yaitu munculnya peluang diantara beberapa variabel bebas untuk saling berkolerasi, pada praktiknya multikolinearitas tidak dapat dihindari. Mengukur multikolinearitas dapat dilihat dari nilai Tolerance dan Variance Inflation Factor (VIF). Tolerance mengukur variabilitas variabel independen lainnya. Jadi nilai tolerance yang rendah sama dengan nilai VIF = 1/tolerance. Nilai cut off yang umum dipakai untuk menunjukkan adanya multikolinearitas adalah nilai nilai tolerance $<0,10$ atau sama dengan VIF $>$ 10. Berikut adalah hasil dari uji multikolinearitas pada Tabel 4.4: 
Tabel 4.4

Uji Multikolinearitas

\begin{tabular}{|c|c|c|}
\hline \multicolumn{3}{|l|}{ Coefficients $^{\mathrm{a}}$} \\
\hline \multirow[b]{4}{*}{ (Constant } & \multirow{2}{*}{\multicolumn{2}{|c|}{$\begin{array}{l}\text { Collinearity } \\
\text { Statistics }\end{array}$}} \\
\hline & & \\
\hline & Tolerance & VIF \\
\hline & & \\
\hline ) & & \\
\hline $\mathrm{X} 1$ & .942 & 1.061 \\
\hline $\mathrm{X} 2$ & .942 & 1.061 \\
\hline
\end{tabular}

a. Dependent Variable: $Y$

Sumber : Data Primer diolah SPSS $22.0(2018)$

Berdasarkan tabel 4.4 di atas, nilai tolerance variabel bebas kualitas sumber daya manusia $(X 1)=0,942$; keterlibatan mahasiswa $(X 2)=0,942$, sedangkan nilai VIF variabel bebas kualitas sumber daya manusia $(X 1)=1,061 ;$ keterlibatan mahasiswa $(X 2)=1,061$. Dapat disimpulkan bahwa model regresi dinyatakan bebas multikolinearitas karena nilai tolerance $>0,10$ dan VIF $<10$.

\section{Uji Heteroskedastisitas}

Uji heteroskedastisitas bertujuan menguji apakah dalam model regresi terjadi ketidaksamaan varians dari residual satu pengamatan ke pengamatan yang lain. Uji statistik yang digunakan uji scatter plot. Dasar analisis adalah jika ada pola seperti titik titik yang membentuk pola terentu yang teratur (bergelombang melebar kemudian menyempit), maka mengindikasikan terjadi heteroskedastisitas. Jika tidak ada pola serta titik titik menyebar diatas dan dibawah angka nol pada sumbu Y, maka tidak terjadi heteroskedastisitas. Dengan bantuan software SPSS diperoleh hasil sebagai berikut :

Gambar 4.3

Uji Heteroskedastisitas

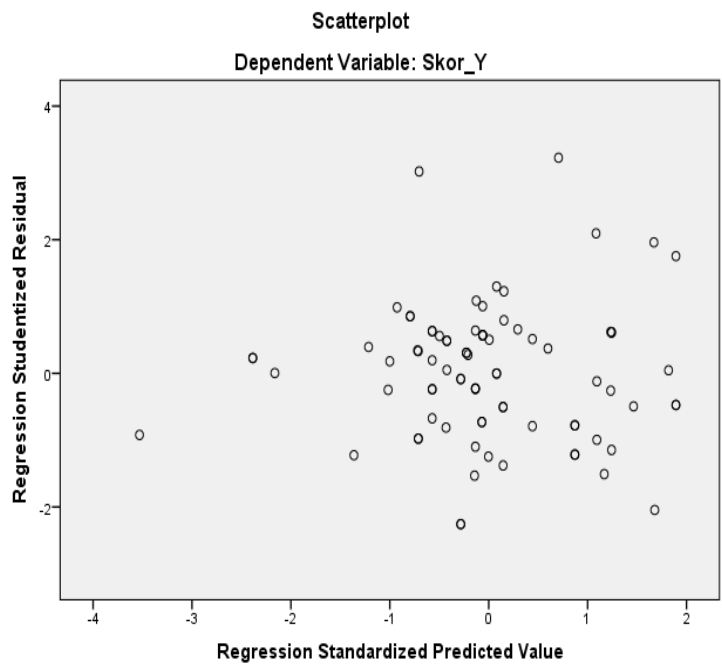

Grafik 4.3 menunjukan bahwa titik titik menyebar secara acak serta tersebar baik diatas maupun dibawah angka nol pada sumbu Y. Sehingga dapat disimpulkan tidak terjadi heteroskedastisitas pada model regresi.

\section{Uji Linearitas}

Uji Linearitas bertujuan untuk mengetahui apakah dua variabel mempunyai hubungan yang linear atau tidak secara signifikan. Pengujian pada SPPS dengan menggunakan Test For Linearitas pada taraf signifikan 0,05. Dua variabel dikatakan mempunyai hubungan yang linier bila siginifikan (linearity) kurang dari 0,05 (Priyatno, 2008:36) Uji Linearitas bertujuan untuk mengetahui apakah dua 
variabel mempunyai hubungan yang linear atau tidak secara signifikan. Pengujian pada SPPS dengan menggunakan Test For Linearitas pada taraf signifikan 0,05. Dua variabel dikatakan mempunyai hubungan yang linier bila siginifikan (linearity) kurang dari 0,05 (Priyatno, 2008)

Tabel 4.5

Coefficients $^{\mathrm{a}}$

\section{Test For Linearity}

\begin{tabular}{|l|l|l|}
\hline Variabel & $F$ & Sig. linearity \\
\hline $\mathrm{X} 1 \rightarrow \mathrm{Y}$ & 2.612 & .402 \\
$\mathrm{X} 2 \rightarrow \mathrm{Y}$ & 4.282 & .398 \\
& & \\
\hline
\end{tabular}

a. Dependent Variable: $Y$

Dari output di atas dapat dilihat bahwa semua variabel memenuhi asumsi linieritas terhadap Y (nilai sig lebih dari 0,05) Dapat disimpulkan bahwa anatara variabel kualitas sumber daya manusia dan keterlibatan mahasiswa terdapat hubungan yang linear.

\section{Analisis Regresi}

Analisis Regresi pada dasarnya adalah studi mengenai ketergantungan variabel dependen (terikat) dengan satu atau lebih variabel independen (variabel penjelas/bebas), dengan tujuan untuk mengestimasi dan /atau memprediksi ratarata populasi ata nila rata-rata variabel dependen berdasarkan nilai variabel independen yang diketahui

\section{Analisis Regresi Berganda}

Menjelaskan tentang bagaimana pengaruh kualitas layanan sumber daya manusia (X1), keterlibatan mahasiswa (X2), terhadap hasil belajar kognitif mahasiswa $(\mathrm{Y})$.

Metode analisis data yang digunakan dalam penelitian ini adalah model analisis regresi liniar berganda untuk mengetahui hubungan antara variabel dependen ( $Y$ ) dengan variabel independen $(X)$. Selain itu juga untuk mengetahui sejauh mana besarnya pengaruh antara variabel dependen $(\mathrm{Y})$ dengan variabel independen $(X)$, secara parsial. Adapun persamaan regresi pada penelitian ini dapat dilihat pada Tabel 4.6 berikut:

Tabel 4.6

Coefficients $^{\mathrm{a}}$

\section{Persamaan Regresi}

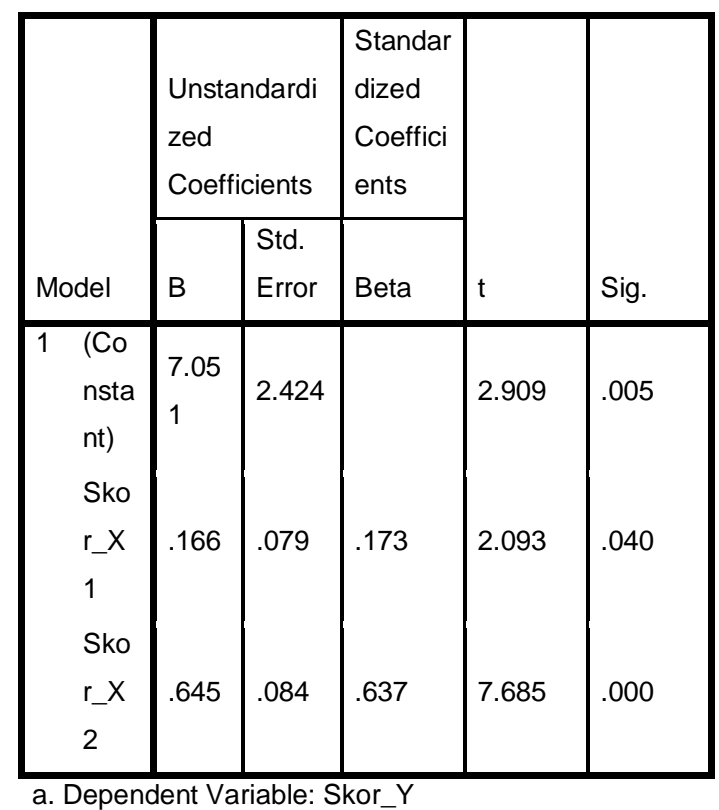


Berdasarkan hasil perhitungan pada tabel 4.6, diperoleh bentuk persamaan regresi linier berganda sebagai berikut :

$$
Y t=\beta 0+\beta 1 X 1+\beta X 2+e
$$

$Y=7.051+0,166 X 1+0,645 X 2+\varepsilon$

Dari persamaan regresi linier berganda diatas diperoleh nilai konstanta sebesar 7.051. Artinya, jika variabel hasil belajar kognitif mahasiswa (Y) tidak dipengaruhi oleh ke enam variabel bebasnya yaitu kualitas layanan sumber daya manusia (X1), keterlibatan mahasiswa(X2), bernilai nol, maka besarnya rata-rata terhadap kinerja sistem informasi akuntansi (Y) akan bernilai 7.051 .

Tanda koefisien regresi variabel bebas menunjukkan arah hubungan dari variabel yang bersangkutan dengan hasil belajar kognitif mahasiswa $(\mathrm{Y})$. Koefisien regresi untuk variabel bebas kualitas layanan sumber daya manusia (X1) bernilai positif, menunjukkan adanya hubungan yang searah antara kualitas layanan sumber daya manusia (X1) dengan hasil belajar kognitif mahasiswa $(Y)$. Koefisien regresi variabel kualitas layanan sumber daya manusia (X1) sebesar 0,166 mengandung arti untuk setiap pertambahan kualitas layanan sumber daya manusia (X1) sebesar satu satuan akan menyebabkan meningkatkan hasil beljar kognitif mahasiswa $(Y)$ sebesar 0,166.
Tanda koefisien regresi variabel bebas menunjukkan arah hubungan dari variabel yang bersangkutan dengan hasil belajar kognitif mahasiswa (Y). Koefisien regresi untuk variabel bebas keterlibatan mahasiswa (X2) bernilai positif, menunjukkan adanya hubungan yang searah antara keterlibatan mahasiswa (X2) dengan hasil belajar kognitif mahasiswa $(\mathrm{Y})$. Koefisien regresi variabel keterlibatan mahasiswa (X2) sebesar 0,645 mengandung arti untuk setiap pertambahan keterlibatan mahasiswa (X2) sebesar satu satuan akan menyebabkan meningkatkan hasil belajar kognitif mahasiswa $(\mathrm{Y})$ sebesar 0,645.

\section{Uji Hipotesis}

Ketetapan fungsi regresi sampel dalam menaksir nilai aktual dapat diukur dari Goodness of fitnya (Ghozali, 2013). Dalam pengujian hipotesis ini dapat dilakukan dengan cara:

\section{Koefisien Determinasi}

Koefisien Determinasi $\left(\mathrm{R}^{2}\right)$ pada intinya mengukur seberapa jauh kemampuan model dalam menerangkan variasi variabel dependen (Ghozali, 2013). Nilai koefisienan determinasi adalah antara nol sampai satu. Nilai $R^{2}$ yang kecil berarti kemampuan variabel independen dalam menjelaskan variasi variabel dependen amat terbatas. Nilai yang mendekati satu berarti variabel-variabel independen memberikan hampir semua informasi yang dibutuhkan untuk 
memprediksi variasi variabel dependen. Jika nilai $R^{2}$ sama dengan satu, maka pendekatan tersebut terdapat kecocokan sempurna dan jika $\mathrm{R}^{2}$ sama dengan nol, maka tidak ada kecocokan pendekatan.

Adjusted $R$ Square adalah nilai $\mathrm{R}$ Square yang telah disesuaian, nilai ini selalu lebih kecil dari R Square dan angka ini bisa memiliki nilai negatif (Priyatno, 2008). Menurut Santoso (dalam Priyatno, 2008) bahwa untuk regresi dengan lebih dari dua variabel bebas digunakan Adjusted $R$ Square sebagai koefisien determinasi.

Tabel 4.7

Adjusted $R$ Square

\section{Model Summary}

\begin{tabular}{|c|c|c|c|c|}
\hline $\begin{array}{l}\text { Mo } \\
\text { del }\end{array}$ & $R$ & $\begin{array}{l}\text { R } \\
\text { Squar } \\
\text { e }\end{array}$ & $\begin{array}{l}\text { Adjusted } \\
\text { R Square }\end{array}$ & $\begin{array}{l}\text { Std. Error } \\
\text { of the } \\
\text { Estimate }\end{array}$ \\
\hline 1 & $.699^{a}$ & .489 & .476 & 2.317 \\
\hline
\end{tabular}

a. Predictors: (Constant), Skor_X2, Skor_X1

Berdasarkan tabel 4.7 dapat diperoleh Aajusted $R$ Square sebesar 0,489 atau $48,9 \%$. Hal ini menenjukan bahwa persentase sumbangan pengaruh variabel kualitas layanan sumber daya manusia (X1), keterlibatan mahasiswa (X2), terhadap variabel dependen hasil belajar kognitif mahasiswa memberikan pengaruh sebesar 48,9\% sedangkan sisanya sebesar $51,1 \%$ dipengaruhi atau dijelaskan oleh variabel lain yang tidak dimasukan dalam model penelitian ini.

\section{Pengujian Hipotesis Secara Bersama (Uji Statistik F)}

Uji signifikansi simultan (uji statistik F) pada dasarnya menunjukkan apakah semua variabel independen atau bebas yang dimasukkan dalam model mempunyai pengaruh secara bersamasama terhadap variabel dependen atau terikat (Ghozali, 2013).

Apabila dari hasil perhitungan dengan bantuan SPSS diperoleh probabilitas $(P$ Value $)<0,05$ maka dapat dikatakan bahwa variabel independen berpengaruh terhadap variabel dependen secara bersama-sama (simultan), sebaliknya apabila diperoleh probabilitas $(P$ Value $)>0,05$ maka dapat dikatakan bahwa variabel independen tidak berpengaruh terhadap variabe/ dependen secara bersama-sama (simultan).

\section{Tabel 4.8}

Pengujian Hipotesis Secara Bersamasama (simultan) $X$ terhadap Y (Uji F)

\begin{tabular}{|ll|l|l|}
\hline \multicolumn{2}{|l|}{ Model } & F & Sig. \\
\hline 1 & Regression & 37.765 & $.000^{\mathrm{b}}$ \\
& Residual & & \\
& Total & & \\
\hline
\end{tabular}

Berdasarrkan tabel 4.8 pada kolom sig. terlihat bahwa nilai signifikansi 0,000 , karena model mempunyai nilai probabilitas kurang dari 0,05 maka dapat disimpulkan bahwa hasil belajar kognitif mahasiswa yang dipengaruhi oleh kualitas layanan sumber daya manusia (X1), keterlibatan 
mahasiswa (X2) mempunyai pengaruh signifikan terhadap hasil belajar kognitif mahasiswa $(Y)$.

Pengujian Hipotesis Secara Parsial (Uji Statisik $\mathbf{t}$ )

Uji staistik $t$ pada dasarnya menunjukan seberapa jauh pengaruh satu variabel penjelas/independen secara individual menerangkan variasi variabel dependen. Untuk mengetahui signifikan atau tidaknya suatu pengaruh dari variabel-variabel bebas secara parsial atas suatu variabel tidak bebas digunakan uji t (Ghozali, 2013).

Berdasarkan hasil pengujian hipotesis dapat diketahui kesimpulan penerimaan atau penolakan hipotesis sebagai berikut:

Tabel 4.9

Pengujian Hipotesis Secara Parsial $X$ terhadap Y (Uji t)

\section{Coefficients $^{\mathrm{a}}$}

\begin{tabular}{|c|l|l|}
\hline Variabel & $\mathrm{T}$ & Sig. \\
\hline X1 & 2.093 & .040 \\
X2 & 7.685 & .000 \\
\hline
\end{tabular}

a. Dependent Variable: $\mathrm{Y}$

Berdasarkan tabel diatas diperoleh hasil sebagai berikut :

1. Variabel $X 1$ memiliki nilai t hitung lebih besar dari nilai $t$ tabel. Karena nilai $t$ hitung $(2,093)<\mathrm{t}$ tabel $(1,994)$ maka Ho ditolak. Oleh karena itu dapat disimpulkan bahwa secara parsial terdapat pengaruh signifikan dari kualitas layanan sumber daya manusia (X1) terhadap hasil belajar kognitif mahasiswa $(\mathrm{Y})$.

2. Variabel $X 2$ memiliki nilai t hitung lebih besar dari nilai $\mathrm{t}$ tabel. Karena nilai $\mathrm{t}$ hitung $(7,685)>t$ tabel $(1,994)$ maka Ho ditolak. Oleh karena itu dapat disimpulkan bahwa secara parsial terdapat pengaruh signifikan dari keterlibatan mahasiswa (X2) terhadap hasil belajar kognitif mahasiswa (Y).

\section{Pembahasan Hasil Uji Hipotesis}

Hipotesis pertama $(\mathrm{H} 1)$ dalam penelitian ini menyatakan terdapat hubungan positif dan signifikan antara kualitas layanan sumber daya manusia denganhasil belajar kognitif mahasiswa. Hasil analisis menunjukan t hitung 2,093 yang lebih besar dari $(>1,994)$ dan nilai signifikan lebih kecil dari 0,05 yaitu 0,040 $(<0,05)$. Kondisi ini menunjukan adanya hubungan positif dan signifikan antara kualitas layanan sumber daya manusia terhadaphasil belajar kognitif mahasiswa.

Hipotesis kedua $(\mathrm{H} 2)$ dalam penelitian ini menyatakan terdapat hubungan positif dan signifikan antara keterlibatan mahasiswa dengan hasil belajar kognitif mahasiswa. Hasil analisis menunjukan $t$ hitung 7,685 yang lebih besar dari $(>1,994)$ dan nilai signifikan lebih kecil dari 0,05 yaitu $0,000(<0,05)$. Kondisi ini menunjukan adanya hubungan positif dan signifikan antara keterlibatan 
mahasiswa terhadap hasil belajar kognitif mahasiswa.

Hipotesis tiga $(\mathrm{H} 3)$ dalam penelitian ini menyatakan terdapat hubungan positif antara kualitas layanan sumber daya manusia dan keterlibata mahasiswa denganhasil belajar kognitif mahasiswa. Hasil analisis menunjukan bahwa $F$ hitung 37,765 yang lebih besar dari $(>3,11)$ dan nilai signifikansi lebih kecil dari 0,05 yaitu $0,000 \quad(<0,05)$. Dengan demikian $\mathrm{H}_{0}$ ditolak dan $\mathrm{H}_{3}$ diterima. Kondisi ini menunjukan bahwa adanya hubungan yang positif dan signifikan antara Apakah kualitas layanan sumber daya manusia dan keterlibatan mahasiswa terhadap hasil belajar kognitif mahasiswa.

Pengaruh Kualitas Layanan Sumber Daya Manusia terhadap Hasil Belajar Kognitif

Berdasarkan hasil pengujian hipotesis penelitian pada Tabel 4.6, Pengaruh kualitas layanan sumber daya manusia terhadap hasil belajar kognitif mahasiswa menghasilkan nilai koefisien (Standarlized Coefficient) positif sebesar 0,173 dan Sig-value sebesar 0,040. Oleh karena itu, Sig-value sebesar $(0,040)<$ sig. tolerance $(0,05)$ maka terdapat pengaruh kualitas layanan sumber daya manusia terhadap hasil belajar kognitif mahasiswa . Hal ini tentu saja mendukung penelitian yang dilakukan sebelumnya oleh Lola $\mathrm{C}$. Duque dan Jhon R. Weeks (2010) dengan judul Towards a model and methodology for assessing student learning outcomes and satisfaction. Dimana hasilnya menyatakan bahwa kualitas sumber daya manusia berpengaruh positif terhadap hasil belajar kognitif mahasiswa. Dengan begitu berarti mahasiswa di Sekolah Tinggi Ilmu Ekonomi Sutaatmadja dan Kolej Universiti Islam Antarbangsa Selangor memiliki rasa kepercayaan bahwa kualitas layanan sumber daya manusia mampu meningkatkan hasil belajar kognitif mahasiswa, ini bisa dilihat dari layanan pendidikan yang diberikan perguruan tinggi baik oleh dosen, bagian akademik dan pihak lainnya yang mampu meningkatkan kepuasan yang dirasakan oleh mahasiswa terhadap hasil belajar kognitif mahasiswa.

\section{Pengaruh Keterlibatan Mahasiswa} terhadap Hasil Belajar Kognitif

Berdasarkan hasil pengujian hipotesis penelitian pada Tabel 4.6, pengaruh keterlibatan mahasiswa terhadap hasil belajar kognitif mahasiswa menghasilkan nilai koefisien (Standarlized Coefficient) positif sebesar 0,637 dan Sigvalue sebesar 0,000 . Oleh karena itu, Sigvalue sebesar $(0,000)<$ sig. tolerance $(0,05)$ maka terdapat pengaruh kualitas layanan sumber daya manusia terhadap hasil belajar kognitif mahasiswa. Hal ini tentu saja mendukung penelitian yang dilakukan sebelumnya oleh Lola C. Duque dan Jhon R. Weeks (2010) dengan judul Towards a model and methodology for assessing student learning outcomes and satisfaction. Dimana hasilnya menyatakan 
bahwa keterlibatan mahasiswa berpengaruh positif terhadap hasil belajar kognitif mahasiswa . Dengan begitu berarti mahasiswa di Sekolah Tinggi IImu Ekonomi Sutaatmadja dan Kolej Universiti Islam Antarbangsa Selangor memiliki rasa kepercayaan bahwa keterlibatan mahasiswa mampu meningkatkan hasil belajar kognitif mahasiswa, ini bisa dilihat dari peran mahasiswa yang aktif mampu memperoleh nilai belajar yang lebih unggul daripada yang pasif.

\section{Pengaruh Kualitas Layanan Sumber} Daya Manusia dan Keterlibatan Mahasiswa terhadap Hasil Belajar Kognitif

Berdasarkan hasil pengujian hipotesis penelitian pada Tabel 4.8, pengaruh simultan variabel kualitas layanan sumber daya manusia dan keterlibatan mahasiswa terhadap hasil belajar kognitif mahasiswa berdasarkan uji $F$ atau ANOVA menghasilkan nilai F hitung 37,765 > 3,11 dan Sig-value sebesar 0,000. Oleh karena itu, Sig-value sebesar $(0,000)<$ sig. tolerance $(0,05)$ maka terdapat pengaruh secara simultan variabel kualitas layanan sumber daya manusia dan keterlibatan mahasiswa terhadap hasil belajar kognitif mahasiswa . Hal ini tentu saja mendukung penelitian yang dilakukan sebelumnya oleh Lola $\mathrm{C}$. Duque dan Jhon R. Weeks (2010) dengan judul Towards a model and methodology for assessing student learning outcomes and satisfaction. Dimana hasilnya menyatakan bahwa kualitas layanan sumber daya manusia dan keterlibatan mahasiswa berpengaruh positif terhadap hasil belajar kognitif mahasiswa. Dengan begitu berarti mahasiswa di Sekolah Tinggi Ilmu Ekonomi Sutaatmadja dan Kolej Universiti Islam Antarbangsa Selangor memiliki rasa kepercayaan bahwa kualitas sumber daya manusia dan keterlibatan mahasiswa mampu meningkatkan hasil belajar kognitif mahasiswa, ini bisa dilihat dari layanan pendidikan yang diberikan oleh perguruan tinggi yang mampu meningkatkan kepuasan mahasiswa terhadap hasil belajar kognitif mahasiswa dan peran mahasiswa yang aktif mampu memperoleh nilai belajar yang lebih unggul daripada yang pasif

\section{KESIMPULAN}

Berdasarkan hasil penelitian mengenai Pengaruh Kualitas Layanan Sumber Daya Manusia dan Keterlibatan Mahasiswa terhadap Hasil Belajar Kognitif Mahasiswa di Perguruan Tinggi (Studi Pada Mahasiswa Sekolah Tinggi IImu Ekonomi Sutaatmadja dan Kolej Universiti Islam Antarbangsa Selangor). Penelitian ini dibagi kedalam dua bagian yang digambarkan dalam model struktural yaitu model struktural yang memprediksi pengaruh dari kualitas layanan sumber daya manusia dan keterlibatan mahasiswa terhadap hasil belajar kognitif mahasiswa, 
sehingga dapat diambil kesimpulan sebagai berikut:

1. Kualitas layanan sumber daya manusia berpengaruh positif dan signifikan terhadap hasil belajar kogitif mahasiswa pada mahasiswa Sekolah Tinggi Ilmu Ekonomi Sutaatmadja dan Kolej Universiti Islam Antarbagsa Selangor. Kondisi ini menunjukan adanya hubungan yang positif dan signifikan antara kualitas layanan sumber daya manusia dan hasil belajar kognitif mahasiswa.

2. Keterlibatan mahasiswa berpengaruh positif dan signifikan terhadap hasil belajar kogitif mahasiswa pada mahasiswa Sekolah Tinggi IImu Ekonomi Sutaatmadja dan Kolej Universiti Islam Antarbagsa Selangor. Kondisi ini menunjukan adanya hubungan yang positif dan signifikan antara keterlibatan mahasiswa dan hasil belajar kognitif mahasiswa.

Kualitas layanan sumber daya manusia dan keterlibatan mahasiswa berpengaruh positif dan signifikan terhadap hasil belajar kogitif mahasiswa pada mahasiswa Sekolah Tinggi Ilmu Ekonomi Sutaatmadja dan Kolej Universiti Islam Antarbagsa Selangor. Kondisi ini menunjukan adanya hubungan yang positif dan signifikan antara kualitas layanan sumber daya manusia, keterlibatan mahasiswa dan hasil belajar kognitif mahasiswa.

\section{REFERENCES}

Abdullah, K. dkk. (1990), Model Program Pendidikan Luar Sekolah Bagi Peningkatan Kesejahteraan Warga dan Keluarga Lapisan Masyarakat Miskin. Bandar Lampung: Universitas Lampung

Abidin, Zainal. (2005). Penghakiman Masa. Jakarta : Erlangga

Ardana. (2012). Manajemen Sumber Daya Manusia. Yogyakarta : Graha Ilmu

Astin, A. W. (1999). Student Involvment : A developmental theory for higher education. Journal of College Student Development, 40(5). 518529

Douglas, J., Douglas, A. and Barnes, B. (2006), "Measuring student satisfaction at a UK university",Quality Assurance in Education, Vol. 14 No. 3, pp. 25167.

Duque, C. Lola and Weeks R. Jhon. (2010), Towards a model and methodology for assessing student learning outcomes and satisfaction,

Harlie, M. (2011), Pengaruh Disiplin Kerja, Motivasi dan Pengembangan Karier terhadap Kinerja Pegawai Negeri Sipil pada Pemerintah Kabupaten Tabalongdi Tanjung Kalimantan Selatan

Hill, F.M. (1995), "Managing service quality in higher education: the role of the student as primary consumer", Quality Assurance in Education, Vol. 3 No. 3, pp. 10-21.

Ndaraha, T. (1999), Makna Pemerintahan. Jakarta: PT Yasif Watampone

Nichols, J.O. (1995), The Department Guide and Record Book for Student Learning Outcomes Assessment and Institutional Effectiveness, Agathon Press, New York, NY

Noviandini, N.C. (2012), Pengaruh persepsi kebermanfaatan, persepsi kemudahan penggunaan, dan kepuasan wajib pajak terhadap 
penggunaan e-filing bagi wajib pajak di Yogyakarta

Peraturan pemerintah RI No.30 tahun 1990

Purwanto, Evaluasi Hasil Belajar, Yogyakarta : Pustaka Belajar, 2009

Rahmah, Noer, Psikologi Pendidikan, Yogyakarta : Teras, 2012

Sopiatin, Popi. (2010), Manajemen Belajar Berbasis Kepuasan Siswa, Bogor : Ghalla Indonesia

Syah Muhhibbin, (2001), Psikologi Belajar, Jakarta : Logos Wacana Ilmu

Binti Maunah, Landasan Pendidikan, Yogyakarta : Teras, 2009Indrawati

Indrawati, A. (2011), Pengaruh Kualitas Layanan Lembaga Pendidikan terhadap Kepuasan Konsumen

Sudarsana, I. K. (2015), Peningkatan Mutu Pendidikan Luar Sekolah Dalam Upaya Pembangunan Sumber Daya Manusia

Taufiq, A. (2014), Hakikat Pendidikan di Sekolah Dasar

Pusat Statistik Pendidikan Badan Penelitian dan Pengembangan Departemen Pendidikan Nasional Republik Indonesia

Dwiyanto, Agus (1995), Penilaian Kinerja

Organisasi Pelayanan Publik. 